IBIMA Publishing

Research in Neurology: An International Journal

http://www.ibimapublishing.com/journals/RNIJ/rnij.html

Vol. 2013 (2013), Article ID 208067, 16 pages

DOI: $10.5171 / 2013.208067$

Research Article

\title{
Alcoholic Polyneuropathy: Clinical Assessment of Treatment Outcomes Following Therapy with Nucleotides and Vitamin $B_{12}$
}

\author{
Carlos Pereira Nunes ${ }^{1}$, Ari Boulanger Scussel Jr ${ }^{2}$, Henrique Goldberg ${ }^{3}$, Gerson \\ Goldwasser ${ }^{4}$, Lisa Oliveira ${ }^{5}$, Helio Rzetelna ${ }^{6}$, Marco Antonio Mibielli ${ }^{7}$, Alessandra Santos ${ }^{8}$ \\ and Mauro Geller ${ }^{9}$ \\ 1,2,5,7 Teresópolis Medical School (UNIFESO), \\ Rio de Janeiro, Brazil \\ ${ }^{3}$ Neurosurgery Service - Hospital Universitário Pedro Ernesto (UERJ), \\ Rio de Janeiro, Brazil \\ ${ }^{4}$ Santa Casa da Misericórdia do Rio de Janeiro, \\ Rio de Janeiro, Brazil \\ ${ }^{6}$ Santa Casa da Misericórdia do Rio de Janeiro, and Universidade Gama Filho Medical School, \\ Rio de Janeiro, Brazil \\ ${ }^{8}$ Instituto de Pós-Graduação Médica Carlos Chagas, Rio de Janeiro, Brazil \\ ${ }^{9}$ Teresópolis Medical School (UNIFESO), and Instituto de Pós-Graduação Médica Carlos Chagas, and Instituto \\ de Puericultura e Pediatria Martagão Gesteira - Federal University of Rio de Janeiro (UFRJ), \\ Rio de Janeiro, Brazil
}

Correspondence should be addressed to: Mauro Geller; mgeller@infolink.com.br

Received date: 3 September 2013; Accepted date: 28 September 2013; Published date: 27 November 2013

Academic Editor: Haruki Koike

Copyright (C) 2013 Carlos Pereira Nunes, Ari Boulanger Scussel Jr, Henrique Goldberg, Gerson Goldwasser, Lisa Oliveira, Helio Rzetelna, Marco Antonio Mibielli, Alessandra Santos and Mauro Geller. Distributed under Creative Commons CC-BY 3.0

Cite this Article as: Carlos Pereira Nunes, Ari Boulanger Scussel Jr, Henrique Goldberg, Gerson Goldwasser, Lisa Oliveira, Helio Rzetelna, Marco Antonio Mibielli, Alessandra Santos and Mauro Geller (2013)," Alcoholic Polyneuropathy: Clinical Assessment of Treatment Outcomes Following Therapy with Nucleotides and Vitamin $B_{12}$ ", Research in Neurology: An International Journal, Vol. 2013 (2013), Article ID 208067,

DOI: $10.5171 / 2013.208067$ 


\begin{abstract}
The purpose of this study was to evaluate the clinical action of the combination of cytidine monophosphate (CMP), uridine triphosphate (UTP), and hydroxocobalamin in the treatment of patients presenting alcoholic polyneuropathy. Patients received a 6-day intramuscular treatment of: CMP 5.0mg; UTP $3.0 \mathrm{mg}$; hydroxocobalamin $2.0 \mathrm{mg}$; lidocaine $20 \mathrm{mg}$, followed by a 30 -day treatment period of thrice daily oral ingestion of: CMP $2.5 \mathrm{mg}$; uridine triphosphate UTP $1.5 \mathrm{mg}$; hydroxocobalamin $1.0 \mathrm{mg}$. Efficacy assessments included a $100 \mathrm{~mm}$ pain VAS, paresthesia testing, motor coordination evaluation, vibration perception testing, and 1-10 point overall condition questionnaire. Safety assessments included vital signs and adverse event monitoring throughout the study. A total of 120 patients were included in the study. The number of symptomatic patients at Assessment 4 was significantly lower in relation to pretreatment for pain $(p=0.0009)$, paresthesia $(\mathrm{p}<0.0001)$, altered vibration perception $(\mathrm{p}=0.0004)$, and altered motor coordination $(\mathrm{p}=0.002)$. VAS score reduction at Assessment 4 was found to be statistically significant $(\mathrm{p}<0.0001)$, with improvement in overall condition assessment scores performed by the patients and the physician ( $\mathrm{p}<0.0001$ for both). Adverse events were observed among 27 patients, and were overall mild or moderate in severity, short-lasting, did not lead to study withdrawal. Based on the results observed in our study, we conclude that the combination of CMP, UTP, and vitamin B $_{12}$ was safe and effective in the treatment of patients presenting alcoholic polyneuropathy. Treatment with the intramuscular injection form followed by oral treatment reduced pain in relation to pretreatment values, increased vitamin $B_{12}$ levels and improved motor coordination among affected patients.
\end{abstract}

Keywords: Alcoholic Polyneuropathy, Uridine, Cytidine, Vitamin $B_{12}$

\section{Introduction}

Alcohol abuse and alcohol dependence are very prevalent conditions in the general population. Alcohol abuse is defined by alterations in control of alcohol consumption, alcohol consumption despite adverse consequences, and distortion in thought patterns, especially denial. These symptoms can be either continuous or periodic (APA, 2000). Alcohol dependence is clinically manifested as continuous use of alcohol despite significant problems associated to alcohol consumption, in addition to increased tolerance to alcohol, abstinence symptoms, and physical manifestations including blackouts or memory lapses after drinking episodes, sleep alterations, and tremors. Alcohol dependence is a chronic disease, associated with malnutrition, trauma, and a wide variety of nervous system dysfunctions, including alcoholic polyneuropathy (Sosenko et al., 1991).
Alcoholic polyneuropathy is a progressive disorder that involves the sensory, motor, and autonomic nerves (Sosenko et al., 1991), distinguishable from beriberi neuropathy by the marked sensory component and significant neuropathic pain (Koike et al., 2001). The most frequent symptoms include numbness, paresthesia, disesthesia with burning sensation, pain, weakness, muscle cramps and gait ataxia. Neurological evaluation frequently reveals loss of tendon reflexes, alterations in tactile perception and vibration perception, weakness and decreased muscle coordination (Kemppainin et al., 1982; Sosenko et al., 1991). The pathophysiology of alcoholic polyneuropathy is thought to be twofold, combining the toxic effect of alcohol with nutritional deficiency caused by longterm heavy alcohol consumption (Koike et al., 2003; Koike \& Sobue, 2006; Koike et al., 2012).

In this study, we evaluated the treatment outcomes following administration of a combination of uridine triphosphate (UTP), 
cytidine monophosphate (CMP), and vitamin $\mathrm{B}_{12}$ in the treatment of patients with alcoholic polyneuropathy. The pyrimidine nucleotides cytidine and uridine have shown beneficial effects in several preclinical studies of peripheral neuropathies of various origins. Beneficial effects have been reported in animal studies following experimentally induced crush injury, with accelerated nerve and muscle fiber regeneration (Wattig et al., 1991; Wattig et al., 1992a; Wattig et al., 1992b). Results of further preclinical investigations have indicated increased nerve conduction velocity, increased levels of neuritic protein neurofilaments, increased axon myelin surface area and thickness, and increased levels of neuronal cell membrane phospholipids phosphatidylcholine and phosphatidylethanolamine following nucleotide administration (Wurtman et al., 2006).

Previously reported clinical findings of cytidine and uridine administration have indicated reduction in pain intensity following treatment in combination with vitamin $B_{12}$. The painful conditions that have been investigated in clinical trial settings with this combination include lumbar and cervical pain, diabetic neuropathy, traumatic-compressive lesions, and acute, non-traumatic pain (Lauretti et al., 2004; Lauretti et al., 2005; Mibielli et al., 2010; Müller 2002a; Müller 2002b; Serra et al., 1972).

The human body requires an exogenous source of vitamin $B_{12}$ in order to maintain a variety of processes vital to health and maintenance - among which are cell reproduction and growth, and nucleoprotein and myelin synthesis (Gubler 1984, p. 245; Wilson 1998, p. 481). In the nervous system, vitamin $\mathrm{B}_{12}$ plays a role in nerve metabolism via the remethylation of homocysteine to methionine for de novo synthesis of $\mathrm{s}$ adenosylmethionine (Chemistry and Biochemistry of B12 1999; Oh \& Brown 2003; Schjonsby 1989). In deficiency states, neurological damage is caused by a disruption of myelin formation that is thought to result from alterations to reactions beginning with sadenosylmethionine (Carmel 2000).
Vitamin $\mathrm{B}_{12}$ absorption depends on five factors - dietary ingestion, the acid-pepsin complex in the stomach that releases cobalamin from its binding proteins, pancreatic proteins that release cobalamin from the $\mathrm{R}$ factor bond, and secretion of intrinsic factor by gastric parietal cells in order to bind cobalamin, and finally, the presence of cobalamin and intrinsic factor receptors in the ileum (Allen et al., 1993). Vitamin $B_{12}$ deficiency can be caused by numerous factors, usually some combination of inadequate ingestion and absorption (Carmel 2000). Deficiency can lead to neurological alterations and megaloblastic anemia; the neurological symptoms of this deficiency are thought to be linked to the absence of s-adenosylmethionine formation (Green \& Kinsella 1995).

\section{Objectives}

The primary study objective was to evaluate the clinical action of the combination of CMP, UTP, and hydroxocobalamin in the treatment of patients presenting alcoholic polyneuropathy. Secondary study objectives included assessment of the combination of CMP, UTP, and hydroxocobalamin in the treatment of patients presenting alcoholic polyneuropathy, using clinical, physical, and laboratory endpoints, as well as adverse events assessment.

\section{Material \& Methods}

The study was performed at UNIFESO university medical facilities in Rio de Janeiro, Brazil. The study was submitted to and approved by the institution's ethical committee (approval no. 593-2011). Eligible subjects included patients of both genders, between the ages of 18 and 65, with a clinical presentation of alcoholic polyneuropathy. Given that there are no established diagnostic criteria for alcoholic neuropathy, after confirmation of alcoholism (per ICD-10 / DSM-IV criteria), we also based on history of alcoholism, history of symptom progression, physical exam (assessing for pain, paresthesia, motor coordination changes, and changes in vibration perception on the lower limbs). 
Female patients performed a urine pregnancy test prior to inclusion and were required to maintain adequate birth control throughout the study period. All patients who agreed to participate gave written informed consent, and were not to consume alcohol during the treatment period.

After screening and pretreatment evaluations, 120 patients received a 6-day intramuscular treatment (administered by the investigating physician) consisting of: cytidine monophosphate (CMP) 5.0mg; uridine triphosphate (UTP) 3.0mg; hydroxocobalamin $2.0 \mathrm{mg}$; and lidocaine $20 \mathrm{mg}$ (for local pain relief). This was followed by a 30-day treatment period of thrice daily oral ingestion of: cytidine monophosphate (CMP) $2.5 \mathrm{mg}$; uridine triphosphate (UTP) $1.5 \mathrm{mg}$; hydroxocobalamin $1.0 \mathrm{mg}$.

A total of 4 study assessments were performed: Assessment 1 (pretreatment), Assessment 2 (following 3 days of intramuscular treatment), and Assessments 3 (following 6 days of intramuscular treatment) and 4 (at the end of the 30 day oral treatment period). At each assessment, a medical history was taken, along with physical and laboratory exams. Use of concomitant medications and occurrence of adverse events were monitored throughout the study.

Efficacy assessments included a $100 \mathrm{~mm}$ pain VAS (visual analog pain scale), paresthesia assessment (using the two-point test), the finger-to-nose test to evaluate motor coordination, and the vibration perception test (performed on the lower limbs using a tuning fork). At each assessment, the patient and the investigating physician evaluated the patient's overall condition on a scale of 1-10 points. At Assessment 4, patients also answered a question regarding their willingness to continue treatment on a scale of 1-10. Safety assessments took into account vital signs at each assessment and occurrence, severity, and duration of any adverse effects, including changes in laboratory tests. These assessments were adopted based on previous clinical studies of alcoholic polyneuropathy (Peters et al. 2006; Woelk et al., 1998).
Results were statistically analyzed using the software GraphPad Prism 5.0. Overall clinical efficacy and tolerability were analyzed via comparison of the results of each assessment in relation to pretreatment values. For categorical variables, we used the $\chi^{2}$ or Fisher's test, while continuous variables were analyzed using the repeated measures ANOVA or Student's T test.

\section{Results}

A total of 120 patients were included in the study. The demographic data and pretreatment characteristics of the study population are summarized in Table 1 . It is important to note that all patients reported consumption of at least two alcoholic drinks per day. Table 2 summarizes the specific symptoms reported at each study visit. The number of patients presenting each symptom at the final study assessment was significantly lower in relation to pretreatment for pain $(p=0.0009)$, paresthesia $(p<0.0001)$, altered vibration perception $(\mathrm{p}=0.0004)$, and altered motor coordination $(\mathrm{p}=0.002)$.

At Pretreatment, mean serum $B_{12}$ levels were $186.7 \mathrm{pg} / \mathrm{mL}$. After 3 days of intramuscular treatment (Assessment 2), mean serum $\mathrm{B}_{12}$ levels increased to $214.3 \mathrm{pg} / \mathrm{mL}$. Mean serum $\mathrm{B}_{12}$ levels at Assessments 3 and 4 were 265.7 and $503.1 \mathrm{pg} / \mathrm{mL}$, respectively. The increase in serum vitamin $\mathrm{B}_{12}$ level from Pretreatment to Assessment 4 was statistically significant ( $<<0.0001$; Fig. 1).

Figure 2 summarizes the results of the motor coordination test. At Pretreatment, 14 (11.67\%) of the patients presented altered motor function. At Assessment 4, this number dropped to 4 patients (3.3\%). The vibration perception test was repeated 3 times, and ranked by the investigating physician as 0 (no perception), 1 (altered perception), or 2 (normal perception). Table 3 summarizes the results of the vibration perception tests performed during the study.

Among the patients presenting pain, mean pretreatment VAS value was $46.78 \mathrm{~mm}$. At Assessment 3, mean VAS value was $40.12 \mathrm{~mm}$; 
while at Assessment 4, mean VAS value decreased to $23.79 \mathrm{~mm}$. VAS score reduction from pretreatment to Assessment 4 was found to be statistically significant $(\mathrm{p}<0.0001)$ (Figure 3).

There was a statistically significant improvement in the scores of the patient's overall condition assessments performed by the patients and the investigating physician from Pretreatment to Assessment 4 ( $p<0.0001$ for both evaluations) (Figure 4).

A total of 27 patients presented with adverse effects, which are summarized in Table 4. The majority of the AEs were mild or moderate in severity, short-lasting, and none caused withdrawal from the study. Table 5 summarizes the safety assessments performed throughout the study.

\section{Discussion}

During the treatment period, we observed clinical improvement in the study subjects as evidenced by the VAS and overall condition assessments performed at each study visit. There were significant reductions in the number of patients presenting pain, paresthesia, altered motor coordination, and vibration perception at end of treatment in relation to pretreatment observations.

The nucleotides may have played a role in the pain reduction experienced among the treated subjects. Although the nucleotides do not exert any direct analgesic or antiinflammatory action, they may contribute to symptomatic improvement in conditions in which peripheral nerves are affected. The neuroregenerative capacity of the pyrimidine nucleotides has been demonstrated in animal models of nerve damage, revealing that both axons and myelin sheaths of regenerating nerve and muscle fibers are favorably influenced by nucleotide administration, with improvements in nerve fiber conduction velocity (Wattig et al., 1991; Wattig et al., 1992a; Wattig et al., 1992b). Clinical benefits of nucleotide administration have been demonstrated in cases of diabetic neuropathy and polyneuropathy as well as neuropathic pain syndrome (Gallai et al., 1992; Müller 2002a; Müller 2002b).

The combination of uridine, cytidine, and vitamin $B_{12}$ has been employed with favorable results in the clinical trial setting in the treatment of a variety of pain syndromes of neural origin, including chronic neuropathic lumbar pain (Lauretti et al., 2005), pain following neurological surgical procedures (Lauretti et al., 2004), neural compressioninduced neuralgias (Goldberg et al., 2009), peripheral neuropathies (Serra et al., 1972), as well as pain and paresthesia in anemic patients (Nunes et al., 2008). Further studies may support additional indications in addition to contribution to a better understanding of the interaction between the nucleotides and Vitamin $\mathrm{B}_{12}$ in painful conditions.

Vitamin $\mathrm{B}_{12}$ and other $\mathrm{B}$ vitamins have been confirmed to exhibit antinociceptive effects that are not associated with vitamin deficiency, in both animal models and in clinical trials (Mauro et al., 2000). On the other hand, $\mathrm{B}_{12}$ deficiency may lead to neurological alterations; sub-acute degeneration of dorsal and lateral spinal columns is the most common manifestation. The latter condition would arise as a result of defective myelin formation (Gomes et al. 2006; Wang et al. 2005).

Vitamin $B_{12}$ has been shown to experimentally inhibit thermal hyperalgesia whether administered alone or in combination with vitamins $\mathrm{B}_{1}$ and $\mathrm{B}_{6}$ (Wang et al., 2005). Administration of vitamin $B_{12}$ resulted in a dose-dependent reduction of tactile allodynia induced by spinal nerve ligation in the rat (Granados-Soto et al., 2004). Patients with mechanical or irritative lumbago and who did not exhibit nutritional deficiency were treated with vitamin $\mathrm{B}_{12}$, resulting in significant improvement in pain and related disability, along with a reduction in paracetamol consumption (Mauro et al., 2000). This effect has been attributed to the effect of vitamin $B_{12}$ on axonal conduction (Wang et al., 2005). In the treatment of patients presenting with diabetic polyneuropathy, treatment with vitamin $\mathrm{B}_{12}$ led to a reduction in pain and paresthesia along with significant 
improvement of ulnar motor and median nerve conduction velocities (Kuwabara et al. 1999).

\section{Conclusion}

Based on the results observed in our study, we conclude that the combination of uridine, cytidine, and vitamin $\mathrm{B}_{12}$ was safe and effective in the treatment of patients presenting alcoholic polyneuropathy. Treatment with the intramuscular injection form followed by oral treatment reduced pain in relation to pretreatment values, increased vitamin $\mathrm{B}_{12}$ levels and improved motor coordination among affected patients.

Figures and Tables

Table 1: Pretreatment and Demographic Characteristics

\begin{tabular}{|c|c|}
\hline Variable & Results \\
\hline \multicolumn{2}{|l|}{ Gender } \\
\hline Male & 89 \\
\hline Female & 31 \\
\hline Age (years) & $46.58( \pm 4.93)$ \\
\hline Height $(\mathrm{cm})$ & $169.8( \pm 6.7)$ \\
\hline \multicolumn{2}{|l|}{ Ethnicity } \\
\hline Black & 36 \\
\hline Caucasian & 42 \\
\hline Mulatto & 42 \\
\hline \multicolumn{2}{|l|}{ Marital status } \\
\hline Divorced & 30 \\
\hline Married & 52 \\
\hline Single & 27 \\
\hline Widowed & 11 \\
\hline \multicolumn{2}{|l|}{ Overall diet } \\
\hline Good & 0 \\
\hline Moderate & 23 \\
\hline
\end{tabular}

Carlos Pereira Nunes, Ari Boulanger Scussel Jr, Henrique Goldberg, Gerson Goldwasser, Lisa Oliveira, Helio Rzetelna, Marco Antonio Mibielli, Alessandra Santos and Mauro Geller (2013), Research in Neurology: An International Journal, DOI: 10.5171/2013. 208067 


\begin{tabular}{|c|c|}
\hline Poor & 97 \\
\hline \multicolumn{2}{|l|}{ Alcohol consumption } \\
\hline$\leq 2$ drinks / day & 0 \\
\hline$>2$ drinks / day & 120 \\
\hline Variable & Results \\
\hline \multicolumn{2}{|l|}{ Cigarette smoking } \\
\hline Non-smoker & 22 \\
\hline$<10$ cigarettes / day & 44 \\
\hline$\geq 10$ cigarettes / day & 54 \\
\hline \multicolumn{2}{|l|}{ Manual labor } \\
\hline Light & 28 \\
\hline Moderate & 34 \\
\hline Heavy & 58 \\
\hline \multicolumn{2}{|l|}{ Physical exercise } \\
\hline Regular (at least $1 \mathrm{x}$ / week) & 0 \\
\hline Irregular & 22 \\
\hline None & 98 \\
\hline
\end{tabular}

Data are $n$ or means $( \pm) S D$

Table 2: Symptoms Recorded at Assessments 1, 3, and 4 (A1, A3, A4)

\begin{tabular}{|c|c|c|c|c|c|c|c|c|c|c|c|c|}
\hline & \multicolumn{3}{|c|}{ Pain } & \multicolumn{3}{|c|}{ Paresthesia } & \multicolumn{3}{|c|}{$\begin{array}{c}\text { Alterations in } \\
\text { vibration perception }\end{array}$} & \multicolumn{3}{|c|}{$\begin{array}{l}\text { Alterations in } \\
\text { motor coordination }\end{array}$} \\
\hline & A1 & A3 & A4 & A1 & A3 & A4 & A1 & A3 & A4 & A1 & A3 & A4 \\
\hline Yes & 120 & 114 & 102 & 47 & 32 & 22 & 34 & 29 & 14 & 18 & 13 & 2 \\
\hline No & 0 & 1 & 8 & 43 & 83 & 90 & 86 & 86 & 106 & 102 & 102 & 110 \\
\hline
\end{tabular}

Data are $n$

Carlos Pereira Nunes, Ari Boulanger Scussel Jr, Henrique Goldberg, Gerson Goldwasser, Lisa Oliveira, Helio Rzetelna, Marco Antonio Mibielli, Alessandra Santos and Mauro Geller (2013), Research in Neurology: An International Journal, DOI: 10.5171/2013. 208067 
Table 3: Results of the Vibration Perception Test recorded at Assessments 1, 3, and 4 (A1, A3, A4)

\begin{tabular}{|r|r|r|r|r|r|r|r|r|r|}
\hline & \multicolumn{3}{|c|}{ Assessment 1 } & \multicolumn{3}{c|}{ Assessment 3 } & \multicolumn{3}{c|}{ Assessment 4 } \\
\hline Scores & Test 1 & Test 2 & Test 3 & Test 1 & Test 2 & Test 3 & Test 1 & Test 2 & Test 3 \\
\hline 0 & 0 & 1 & 1 & 0 & 0 & 0 & 0 & 0 & 0 \\
\hline 1 & 31 & 37 & 41 & 32 & 31 & 32 & 22 & 15 & 17 \\
\hline 2 & 89 & 82 & 78 & 83 & 84 & 83 & 90 & 97 & 95 \\
\hline
\end{tabular}

Data are $n$

Table 4: Adverse Events

\begin{tabular}{|c|c|c|}
\hline Adverse Events & Severity & \# of Subjects Affected \\
\hline Abdominal distension & Moderate & 1 \\
\hline Abdominal distension & Mild & 1 \\
\hline Agitation & Moderate & 1 \\
\hline Anxiety & Mild & 1 \\
\hline Breast pain & Moderate & 1 \\
\hline Constipation & Moderate & 2 \\
\hline Adverse Events & Severity & \# of Subjects Affected \\
\hline Cough & Moderate & 1 \\
\hline Diarrhea & Moderate & 1 \\
\hline Diarrhea & Mild & 1 \\
\hline Epigastralgia & Mild & 1 \\
\hline Epigastralgia & Moderate & 1 \\
\hline Erithema at injection site & Moderate & 1 \\
\hline Flatulence & Moderate & 1 \\
\hline Headache & Moderate & 4 \\
\hline
\end{tabular}




\begin{tabular}{|c|c|c|}
\hline Adverse Events & Severity & \# of Subjects Affected \\
\hline Headache & Severe & 1 \\
\hline Headache & Mild & 2 \\
\hline Heartburn & Moderate & 1 \\
\hline Hemorrhoids & Moderate & 1 \\
\hline Hyperemia at injection site & Moderate & 1 \\
\hline Increased uric acid & Mild & 1 \\
\hline Insomnia & Severe & 4 \\
\hline Irritability at injection site & Moderate & 1 \\
\hline Loss of appetite & Moderate & 4 \\
\hline Muscle cramp & Severe & 1 \\
\hline Nausea & Mild & 6 \\
\hline Nausea & Moderate & 7 \\
\hline Pain at injection site & Moderate & 5 \\
\hline Pyrosis & Moderate & 2 \\
\hline Vomiting & Moderate & 2 \\
\hline Vomiting & Severe & 1 \\
\hline
\end{tabular}

Data are $n$

Table 5: Safety Assessments

\begin{tabular}{|l|c|l|}
\hline \multicolumn{1}{|c|}{ Parameters } & Results & Change from pretreatment \\
\hline Weight (kg) & & No $(\mathrm{p}=0.184)$ \\
\hline A1 & $64.6( \pm 10.68)$ & \\
\hline A2 & $64.18( \pm 10.45)$ & \\
\hline A3 & $64.17( \pm 10.19)$ & \\
\hline A4 & $64.71( \pm 9.27)$ & \\
\hline
\end{tabular}

Carlos Pereira Nunes, Ari Boulanger Scussel Jr, Henrique Goldberg, Gerson Goldwasser, Lisa Oliveira, Helio Rzetelna, Marco Antonio Mibielli, Alessandra Santos and Mauro Geller (2013), Research in Neurology: An International Journal, DOI: 10.5171/2013. 208067 


\begin{tabular}{|c|c|c|}
\hline Parameters & Results & Change from pretreatment \\
\hline BMI & & No $(p=0.254)$ \\
\hline A1 & $22.33( \pm 2.94)$ & \\
\hline A2 & $22.21( \pm 2.85)$ & \\
\hline A3 & $22.19( \pm 2.77)$ & \\
\hline A4 & $22.33( \pm 2.41)$ & \\
\hline Systolic Blood Pressure (mmHg) & & Yes $(p=0.0006)$ \\
\hline A1 & $127.7( \pm 5.61)$ & \\
\hline $\mathrm{A} 2$ & $127.4( \pm 5.61)$ & \\
\hline A3 & $127.2( \pm 5.72)$ & \\
\hline $\mathrm{A} 4$ & $126.5( \pm 5.03)$ & \\
\hline Diastolic Blood Presssure (mmHg) & & Yes $(p=0.0283)$ \\
\hline A1 & $84.93( \pm 7.74)$ & \\
\hline A2 & $84.69( \pm 7.92)$ & \\
\hline A3 & $84.17( \pm 8.24)$ & \\
\hline $\mathrm{A} 4$ & $84.27( \pm 7.81)$ & \\
\hline Pulse (bpm) & & No $(p=0.0892)$ \\
\hline A1 & $71.08( \pm 4.67)$ & \\
\hline A2 & $70.51( \pm 4.51)$ & \\
\hline A3 & $70.40( \pm 4.5)$ & \\
\hline $\mathrm{A} 4$ & $70.59( \pm 4.33)$ & \\
\hline
\end{tabular}




\begin{tabular}{|l|c|l|}
\hline \multicolumn{1}{|c|}{ Parameters } & Results & Change from pretreatment \\
\hline Respiratory rate (ipm) & & No $(\mathrm{p}=0.355)$ \\
\hline A1 & $17.83( \pm 7.78)$ & \\
\hline A2 & $17.94( \pm 7.52)$ & \\
\hline A3 & $16.86( \pm 2.12)$ & \\
\hline A4 & $17.13( \pm 4.63)$ & \\
\hline
\end{tabular}

Data are means $(\underline{+S D})$

Serum Vitamin B12 Levels

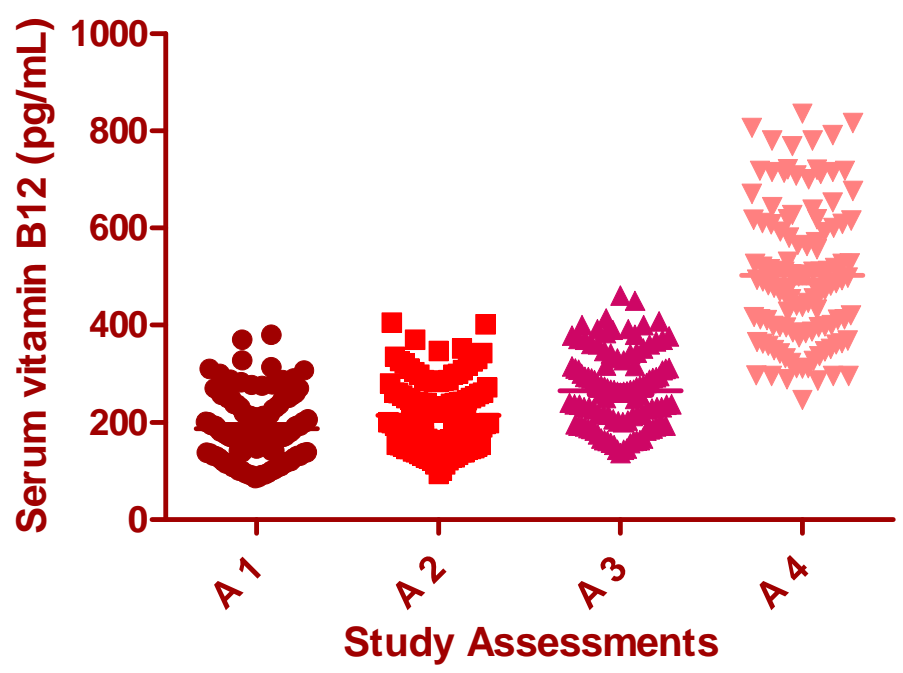

Figure 1: Serum Vitamin B12 Levels At Assessments 1, 2, 3, and 4

Figure 1 shows a statistically significant increase in serum vitamin $B_{12}$ level from Pretreatment to Assessment $4(\mathrm{p}<0.0001)$

Carlos Pereira Nunes, Ari Boulanger Scussel Jr, Henrique Goldberg, Gerson Goldwasser, Lisa Oliveira, Helio Rzetelna, Marco Antonio Mibielli, Alessandra Santos and Mauro Geller (2013), Research in Neurology: An International Journal, DOI: 10.5171/2013. 208067 


\section{Motor Coordination Test}

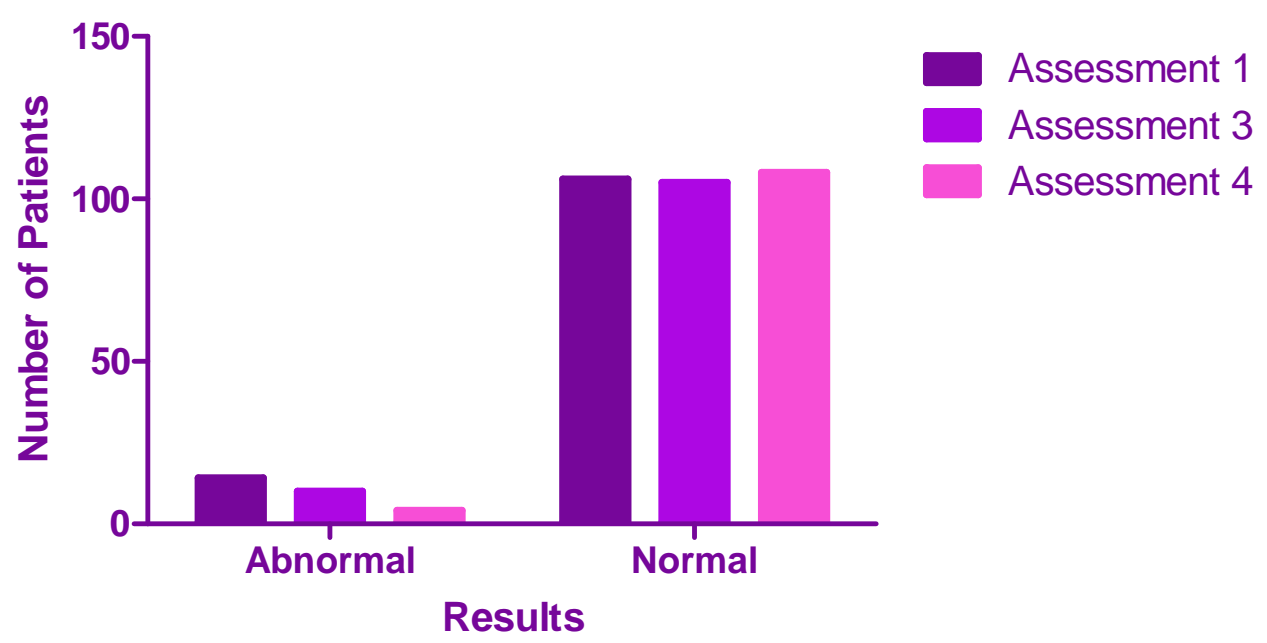

Figure 2: Results of the Motor Coordination Test at Assessments 1, 3, and 4

Figure 2 summarizes the results of the motor coordination test performed at each study Assessment, displaying the number of patients with normal or abnormal results at each assessment.

\section{VAS Scores}

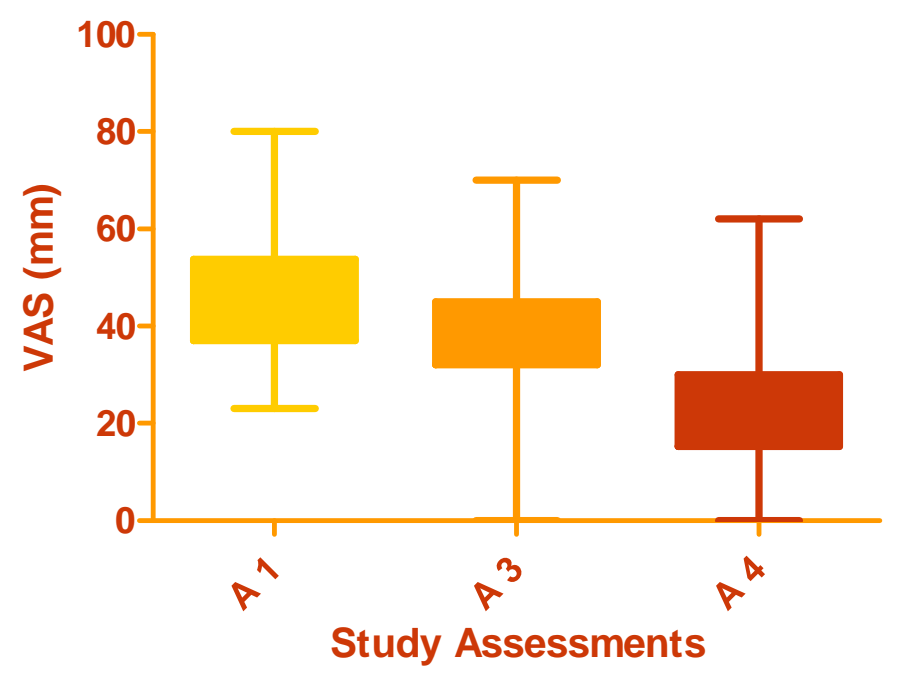

Figure 3: Visual Analog Pain Scale Scores at Assessments 1, 3, and 4

Figure 3 shows significant VAS score reduction from pretreatment to Assessment $4(\mathrm{p}<0.0001)$.

Carlos Pereira Nunes, Ari Boulanger Scussel Jr, Henrique Goldberg, Gerson Goldwasser, Lisa Oliveira, Helio Rzetelna, Marco Antonio Mibielli, Alessandra Santos and Mauro Geller (2013), Research in Neurology: An International Journal, DOI: 10.5171/2013. 208067 


\section{Patient's Assessment of Overall Condition (Patient Scores)}

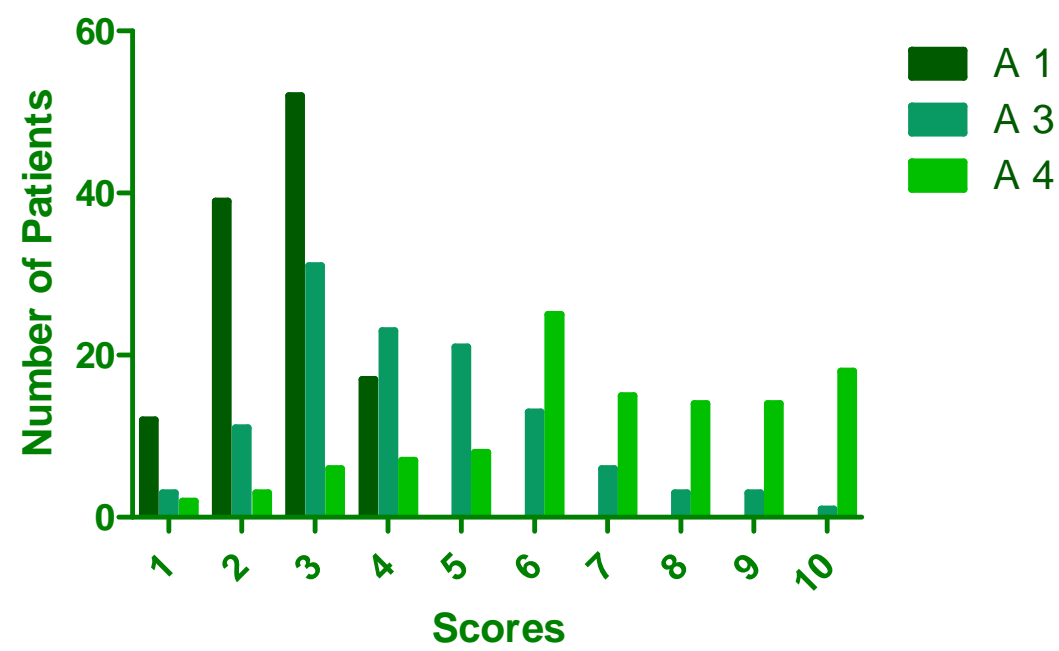

\section{Patient's Assessment of Overall Condition (Physician Scores)}

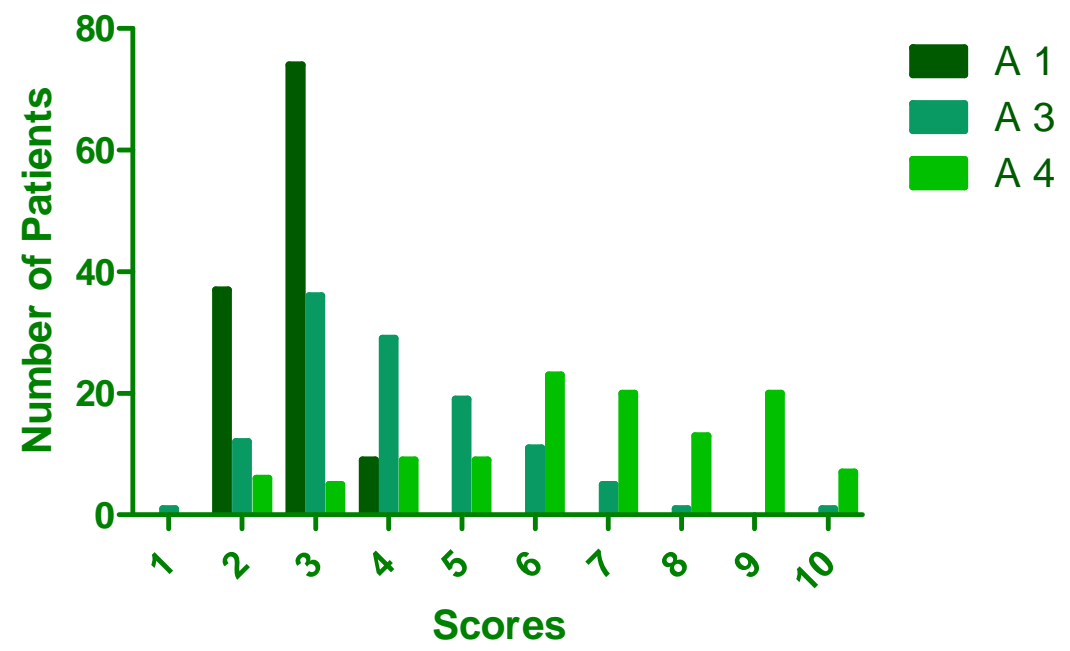

Figure 4: Assessment of Overall Condition Scores (as evaluated by the patient and physician)

Figure 4 shows the improvement in scores of the patient's overall condition assessments performed by the patients and the investigating physician from Pretreatment to Assessment $4 \quad(\mathrm{p}<0.0001$ for both evaluations).

\section{Acknowledgment}

The authors would like to thank Renata Kuperman for CRF data entry, Natasha Cytrynbaum and Flavia Dwek for CRF data verification, and Breno Lorch for monitoring. 


\section{References}

Allen, R.H., Stabler, S.P., Savage, D.G., and Lindenbaum, J. (1993) Metabolic abnormalities in cobalamin (vitamin B12) and folate deficiency. FASEB Journal: official publication of the Federation of American Societies for Experimental Biology, 7:13441348.

APA. Diagnostic and statistical manual of mental disorders $-4^{\text {th }}$ edition text revision (DSM-IV-TR). American Psychiatric Association, Washington, DC, 2000.

Carmel, R. (2000) Current concepts in cobalamin deficiency. Annual Review of Medicine, 51:357-75.

Chemistry and Biochemistry of B12. 1999, John Wiley \& Sons Inc, New York.

Gallai, V., Mazzotta, G., Montesi, S., Sarchielli, P., and Del Gatto, F. (1992) Effects of uridine in the treatment of diabetic neuropathy: an electrophysiologic study. Acta Neurologica Scandinavica, 86:3-7.

Goldberg, H., Scussel Jr, A.R., Cohen, J.C., Rzetelna, H., Mezitis, S.G.E, Nunes, F.P., Ozeri, D., Daher, J.P.L., Nunes, C.P., Oliveira, L., and Geller, M. (2009) Neural compressioninduced neuralgias: clinical evaluation of the effect of nucleotides associated with vitamin B12. Revista Brasileira de Medicina, 66(11):380-5.

Gomes, A.V.C., Coutinho, C., and Geller, M. (2006) Therapeutic properties of the Bcomplex vitamins (B1, B6, B12) and their pharmacologic associations. Revista Brasileira de Medicina, 63(3): 111-7.

Granados-Soto, V., Sánchez-Ramirez, G., la Torre, M.R., Caram-Salas, N.L., MedinaSantillán, R., and Reyes-García, G. (2004) Effect of diclofenac on the antiallodynic activity of vitamin B12 in a neuropathic pain model in the rat. Proceedings of the Western Pharmacology Society, 47:92-4.
Green, R., and Kinsella, J.L. (1995) Editorial: Current concepts in the diagnosis of cobalamin deficiency. Neurology, 45:1435.

Gubler, C.J. In: Handbook of vitamins: Nutritional, biochemical, and clinical aspects. 1984. Machlin, L.J. (ed), Marcel Dekker, New York, p. 245.

Kemppainin, R., Juntunen, J., and Hillbom, M. (1982) Drinking habits and peripheral alcoholic neuropathy. Acta Neurologica Scandinavica, 65:11-18.

Koike, H., Hama, T., Kawagashira, Y., Hashimoto, R., Tomita, M., Iijima, M., and Sobue, G. (2012) The significance of folate deficiency in alcoholic and nutritional neuropathies: analysis of a case. Nutrition, 28:821-824.

Koike, H., Iijima, M., Sugiura, M., Mori, K., Hattori, N., Ito, H., Hirayama, M., and Sobue, G. (2003) Alcoholic neuropathy is clinicopathologically distinct from thiaminedeficiency neuropathy. Annals of Neurology, 54(1):19-29.

Koike, H., Mori, K., Misu, K., Hattori, N., Ito, H., Hirayama, M., and Sobue, G. (2001) Painful alcoholic polyneuropathy with predominant small-fiber loss and normal thiamine status. Neurology, 56(12):1727-1732.

Koike, H., Sobue, G. (2006) Alcoholic neuropathy. Current Opinion in Neurology, 19(5):481-486.

Kuwabara, S., Nakazawa, R., Azuma, N., Suzuki, M., Miyajima, K., Fukutake, T., and Hattori, T. (1999) Intravenous methylcobalamin treatment for uremic and diabetic neuropathy in chronic hemodialysis patients. Internal Medicine, 38(6):472-475.

Lauretti, G.R., Omais M., Pereira, A.C., and Mattos, A.L. (2004) Avaliação clínica do efeito analgésico do complexo citidina-uridinahidroxocobalamina como coadjuvante no tratamento da dor lombar crônica neuropática. Coluna, 3(2):73-6. 
Lauretti, G.R., Trevelin, W.R., and Frade, L.C.P. (2005) Neuroplastia por via caudal em pacientes portadores de dor lombar póslaminectomia. Coluna, 4(1):27-30.

Mauro, G.L., Martorana, U., Cataldo, P., Brancato, G., and Letizia, G. (2000) Vitamin B12 in low back pain: a randomized, doubleblind, placebo-controlled study. European Review for Medical and Pharmacological Sciences, 4(3):53-8.

Mibielli, M.A., Nunes, C.P., Cohen, J.C., Scussel, A.B. Jr, Higashi, R., Bendavit, G.G., Oliveira, L., Geller, M. (2010) Treatment of acute, nontraumatic pain using a combination of diclofenac-cholestyramine, uridine triphosphate, cytidine monophosphate, and hydroxocobalamin. Proceedings of the Western Pharmacology Society, 53:5-12.

Müller, D. (2002) Pilotstudie mit pyrimidinnukleotiden. Weniger Schmerzen bei diabetischer polyneuropathie. MMW Fortschritte der Medizin, 144(46):61.

Müller, D. (2002) Therapie de neuropathischen schemerzsyndroms: Ergebnisse einer offenen studie zur wirksamkeit eines pyrimidinnukleotidPraparats. Fortschritte der Medizin Originalien. 120(4):131-133.

Nunes, C.P., Higashi, R., Ribeiro, M.G., Fonseca, A.D.S., Leite, A.C.C.B., Krymchantowski, A.V., Nunes, F.P., Goldberg, S.W., Coutinho, M.P., Kaufman, R., Darrigo Jr, L.G., and Geller, M. (2008) Efficacy and tolerability of a combination of uridine, cytidine, and vitamin B12 in anemia. A double-blind, comparative study versus nucleotide monotherapy. Revista Brasileira de Medicina; 65:15-21.

Oh, R., and Brown, D.L. (2003) Vitamin B12 deficiency. American Family Physician, 67:979-86.

Peters, T.J., Kotowicz, J., Nyka, W., Kozubski, W., Kuznetsov, V., Vanderbist, F., de Niet, S., Marcereuil, D., and Coffiner, M. (2006) Treatment of alcoholic polyeneuropathy with vitamin B complex: a randomised controlled trial. Alcohol and Alcoholism, 41(6):636-642.

Schjonsby, H. (1989) Vitamin B12 absorption and malabsorption. Gut, 30:1986-91.

Serra, J.P., Veciana, M.G., and Bordas, L.B. (1972) Efectos terapéuticos de una asociación de C.M.P., U.T.P., y vitamina B12 en cincuenta casos de neuropatias perifericas. New England Journal of Medicine (Spanish Edition), VI(64):1-7.

Sosenko, J.M., Sotor, R., Arnson, J., Kato, M. Caralis, P.V., and Ayyar, D.R. (1991) The prevalence and extent of vibration sensitivity impairment in men with chronic ethanol abuse. Journal of Studies on Alcohol and Drugs, 52:374.

Wang, Z.B., Gan, Q., Rupert, R.L., Zeng, Y.M., and Song, X.J. (2005) Thiamine, pyridoxine, cyancobalamin and their combination inhibit thermal, but not mechanical hyperalgesia in rats with primary sensory neuron injury. Pain, 114:266-277.

Wattig, B., Heydenreich, F., Schalow, G., Radzewitz, B., Warzok, R., and CervosNavarro, J. (1991) Nucleotide beschleunigen die nervenregeneration. Z Klin Med, 46:13713.

Wattig, B., Schalow, G., Heydenreich, F., Warzok R., and Cervós-Navarro J. (1992) Enhancement of nerve fibre regeneration by nucleotides after peripheral nerve crush damage. Electrophysiologic and morphometric investigations. ArzneimittelForschung/Drug Research, 42(II); 9:10751078.

Wattig, B., Schalow, G., Madauss, M., Heydenreich, F., Warzok, R., and CervosNavarro, J. (1992) Acceleration of nerve and muscle regeneration by administration of nucleotides - electroneurophysiological and morphometrical investigations. Acta Histochemica, Suppl-Band XLII; S:333-9.

Wilson, J.A. Vitamin deficiency and excess. In: Harrison's Principles of Internal Medicine.

Carlos Pereira Nunes, Ari Boulanger Scussel Jr, Henrique Goldberg, Gerson Goldwasser, Lisa Oliveira, Helio Rzetelna, Marco Antonio Mibielli, Alessandra Santos and Mauro Geller (2013), Research in Neurology: An International Journal, DOI: 10.5171/2013. 208067 
$14^{\text {th }}$ Ed. 1998, Fauci AS, Braunwald E, Isselbacher K (eds) et al. McGraw-Hill, New York, p. 481.

Woelk, H., Lehrl, S., Bitsch, R., and Köpcke, W. (1998) Benfotiamine in treatment of alcoholic polyneuropathy: na 8-week randomized controlled study (BAP I Study). Alchol and Alcoholism, 33(6):631-638.
Wurtman, R.J., Ulus, I.H., Cansev, M., Watkins, C.J., Wang, L., and Marzloff, G. (2006) Synaptic proteins and phospholipids are increased in the gerbil brain by administering uridine plus docosahexanoic acid orally. Brain Research, 1088:83-92. 